\title{
最近の歯学
}

\section{7. 口貯外科}

線維素融酵素による対炎症治療

口腔外科学教室 伊 藤 秀 夫, 志 村介三

生体の一部に外傷(手術を含む) を受けたり，また細菌 感染が起る上，そ机に対する生体の反忘上して滲出が現 わ机る。すなわち、充血にはじまつて，血管壁の変化を 招来し，そのために，血液成分が組織内に滃出して水腫 上腫脹が起つてくる。血液蛋白である fibrinogen は fibrin にかわつて，線維素網在形成する。この線維素網 の蓄積は，血液の凝固上相まつて，リンパの環流を妨げ るので，水腫がさらに増大するばかりでなく，治癒過程 の進行を著しくおくらせる。従来は, 感染症の治療や, 感染予防の手段の主体が, 病原菌の征圧におかれて, も つぱらサルファ剂や抗生剤の抗菌作用にたよつていたの であるが、このような状態のも上に化学療法を行つて も，薬剤が体液の環流障害や厚い線維素壁などにさえぎ られて，充分に病巣に到達できないために，期待するよ らな薬治効果がえられないことも少くなかつた。ところ が，近年になつて，強い蛋白消化作用のある tripsin が 治療薬として認識され、これを筋注することによつて, 水腫が速やかに消失し、また, 炎症の治癒期間が短縮す ることが，動物実験ならびに臨床で実証されてから，各 種の蛋白あるいは線維素融解酵素が，壊死組織の融解 や，血腫，水腫などの消退の目的に使用されるようにな つた。こ机は対炎症, 対水腫療法の大きな進歩であり, 将来の治療のあり方の道標ともなるものと思う。

ここに紹介する Varidase 口腔錠もその1つである。 Varidase は一錠中に Streptokinase (Tilletet et al. 1933, Christensen 1945, ら) 10,000 単位と, Streptodornase (Tillet et al. 1938, Sherry et al. 1950, 5) 2,500 単 位上が含まれている。Streptokinase は非病原性溶血性連 鎖球菌の産生する線維素融解酵素で, 人の血清中の plasminogen 賦活系に働いて, plasminogen を活性系の plasmin にかえ, plasmin は線維素の長い蛋白鎖を切断
して，分子量の低い可溶性蛋白質ないしは polypeptide にまで分解して，吸収され易い状態にする。また， Streptodornase は粗製 Streptokinase 中に存在する核蛋 白融解酵素で，これを粗大沈降物を大量に含む濃厚な膿 性滃出物に作用させると, 膿汁は急速に稀薄液化して, 粘稠度が低下し, 膿汁内に酸溶性の有機燐と窒素が増加 し，壊死白血球が著明に減少する。

使用法は，1日 4 錠で，1回に1 錠を犬歯窩部の歯肉 と煩粘膜との間に入れ，自然に溶解するのを待つ。挿入 場所としては，下顎臼歯部の舌下口底部も良い。投与期 間は症状によつてことなるが，平均 5 〜 日で，水腫の 消退老まつて，その投与在止める。

このようにして使用さ机た Varidase は唾液によつく 溶解され, 口腔粘膜から吸収された 2 つの酵素, 寸なわち Streptokinase こStreptodornase の作用によつて, 線維 素壁，過剩血餅，あるい:壊死組織の融解，滲出物の液 化と限局化などが比較的急速に行われるので，水腫，腫 脹が減少し, 疼痛が緩解するばかりでなく, 病巣部にお ける体液の環流が良くなるので，化学療法剤の病巣への 到達が容易となり，炎症の治療期間が短縮される。

したがつて，Varidase は水腫性腫脹を伴う種々の炎 症性疾患に対して使用されるが，口腔領域における適応 症は，各種の化膿性炎，炎症性開口障害，外傷または手 術後に起こる反応性腫脹や過剩の血餅形成の予防と治療 などで，また，線維素性偽膜で被われた潰瘍性口内炎な どにも有効である。なお，副作用としては，稀ではある が, 局部的な力タル性口内炎, 胸やけ, 腹部膨満感, 胃 違和感のような軽度の胃腸障害が一時的に現われること がある。なお，血液凝固機構に欠陥がある患者には，使 用しない方が良い。 